\section{Intersectional Hybridization among Trichostema Species}

\author{
Bruce L. Dunn ${ }^{1,3}$ and Jon T. Lindstrom ${ }^{2}$ \\ Department of Horticulture, University of Arkansas, 316 Plant Sciences \\ Building, Fayetteville, AR 72701
}

Additional index words. ornamental plant breeding, blue curls, interspecific hybrid, intersectional hybrid, hybrid sterility

\begin{abstract}
Controlled reciprocal crosses between Trichostema lanatum Benth. (section Chromocephalum F.H. Lewis) with Trichostema arizonicum A. Gray (section Paniculatum F.H. Lewis) and Trichostema purpusii Brandegee (section Rhodanthum Lewis) were successful in generating the first artificial hybrids in the genus. Crosses where T. lanatum was used as the female were unsuccessful. Leaf and floral morphology among the hybrids was typically intermediate. Female sterility was seen in the $T$. arizonicum $\times T$. lanatum hybrids, and these hybrids also produced abnormally small, nonviable pollen grains. Propagation procedures are also presented. Although these species may be in different sections, their crossability suggests that they are closely related.
\end{abstract}

Trichostema L., a North American genus in the Lamiaceae family comprised of annual and perennial species, is found growing across the continental United States and extending north into Canada and south into Mexico (Lewis, 1960). Of the species, the perennial T. lanatum, also known as romero or woolly blue curls, is probably the most recognizable species, as it is commercially available and is used in California landscapes (Clausen and Ekstrom, 1989; Crane 2007; Evans and Bohn, 2001; Wilson 2007). Trichostema spp. grows vigorously during the summer and early autumn dry season, making it an excellent plant for xeriscaping (Dalby, 2004; Heisey and Delwiche, 1984). The flowers are also reported to have a pleasant, aromatic fragrance, and are a favorite of hummingbirds and butterflies (Crane, 2007; Dalby, 2004). Not all species are of ornamental value, as a number of annual species, including T. brachiatum L., T. dichotomum L., and T. setaceum Houtt., are reported as weedy (Lewis, 1945).

The exact number of species has been unclear in the literature, although 16 species was reported as late as 1978 (Lewis and Rzedowski, 1978). Epling (1940) had suggested that $T$. mexicanum Epling could be separate from $T$. arizonicum based on reduced hairiness, flower size, and branching inflorescences. Lewis (1945) considered $T$. mexicanum to fall within the range of $T$. arizonicum and thus to be synonymous with T. arizonicum. Henrickson (1982) agreed with Epling that T. mexicanum is a distinct species based on corolla size and color, anther length, inflorescence habit, growth

Received for publication 21 Aug. 2007. Accepted for publication 2 Oct. 2007.

${ }^{1}$ Graduate student, University of Arkansas.

${ }^{2}$ Associate professor, University of Arkansas.

${ }^{3}$ To whom reprint requests should be addressed; e-mailbldunn@uark.edu habitat, and distribution. Lewis (personal communication) agreed that $T$. mexicanum should be considered a separate species. He recently described another species, T. ruygtii $\mathrm{H}$. Lewis, and notes its close relationship to T. lanceolatum Benth. (Lewis, 2006). This brings the total to 18 species.

Originally, Lewis had proposed five sections (Chromocephalum, Paniculatum, Rhodanthum, Orthopodium Benth., and Trichostema Benth.) based on flower morphology, chromosome counts, and growth habit (Lewis, 1945). Trichostema purpusii (formerly the monotypic genera Eplingia L.O. Williams) was originally placed in sect. Rhodanthum, as Lewis (1945) notes only remote similarities with any of the other species. However, upon germination of some collected T. purpusii seed, Lewis and Rzedowski (1978) later reported that $T$. purpusii and $T$. arizonicum were more closely related to each other than any other species in the genus; therefore, he included $T$. purpusii with $T$. arizonicum in sect. Paniculatum. Huang (2002) agreed with Lewis's original decision to separate the species into their individual sections by reporting $n d h F$ data showing sect. Paniculatum and Rhodanthum as being sisters to one another, and thus T. purpusii will be considered in sect. Rhodanthum.

Sections Chromocephalum and Paniculatum were reported to have $n=10$ chromosomes, whereas other chromosome numbers within the genus vary among the species and even sections, ranging from $n=7$ to $n=19$ (Lewis, 1960). Two shrubby perennial California species are included in sect. Chromocephalum: T. lanatum and T. parishii Vasey.

Section Trichostema species observed in the wild generally grow in isolated populations; however, Lewis $(1945,2006)$ did report that some species can be found growing together where boundaries overlap, as in the case of $T$. parishii and T. lanatum populations, as well as T. ruygtii and T. lanceolatum. No intermediate hybrids have been reported for sect. Trichostema from field observations, even though interspecific hybridization within Lamiaceae is reported to be common and has been seen in Salvia L., Mentha L., Monarda L., Dicerandra Benth., and Hyptis Jacq. (Huck, 1992). Lewis (personal communication) attempted crosses between $T$. lanatum and $T$. parishii, both sect. Chromocephalum, with no success.

Thus, little is known of the breeding compatibility among the species. Artificial hybridization yields information on crossability, hybrid fertility, and the genetic contributions to a phenotype, all of which give insight into the relationship among species (Kruckeberg, 1962). The main objective of this work was to assess the genetic relationship through interspecific hybridization between three ornamental perennial Trichostema species: T. lanatum (sect. Chromocephalum), T. purpusii (sect. Rhodanthum), and T. arizonicum (sect. Paniculatum).

\section{Materials and Methods}

Hybridization. A single plant of T. lanatum was raised from seed obtained from Southwestern Native Seeds (Tucson, AZ). Seed of T. arizonicum was also obtained from the same source. Seed of T. purpusii was obtained from Seedhunt (Freedom, CA). All three species of Trichostema were maintained under greenhouse conditions. T. arizonicum and $T$. purpusii are dormant in winter and were kept cool (minimum winter temperature $50{ }^{\circ} \mathrm{F}$ ) and dry. Trichostema lanatum grows throughout the year, with most flowers occurring in the spring, summer, and early fall. Controlled reciprocal pollinations between $T$. arizonicum $\times T$. lanatum were made beginning on 24 Aug. 2004. Controlled reciprocal pollinations between $T$. purpusii $\times T$. lanatum were made beginning on 12 Sept. 2006. Flowers were emasculated using tweezers before anthesis. Pollination occurred once a day for $3 \mathrm{~d}$ after emasculation. At least five flowers were used in each crossing experiment.

Mature seeds from the T. arizonicum $\times T$. lanatum cross were collected on 5 Nov. 2004, and were subsequently sown on 1 Dec. 2004. Mature seeds from the $T$. purpusii $\times T$. lanatum cross were collected on 10 Nov. 2006, and were subsequently sown on 12 Nov. 2006. All seeds were planted in pots using a 1:1 ratio of Fafard \#2 (Portland, OR) mix and perlite that had been autoclaved and pretreated with boiling water. Pots were placed in a Park Seed Biodome ${ }^{\mathrm{TM}}$ (Greenville, SC) until seeds germinated.

Pollen viability. Pollen comparisons were made on pollen collected from mature anthers on greenhouse specimens of $T$. arizonicum $\times T$. lanatum hybrids. Anthers from at least five flowers were used. Anthers were squashed on a microscope slide containing two to three drops of $1 \%$ acetocarmine. Measurements (based on 10 pollen grains per species) of the polar and equatorial axes were made with a light microscope $(\times 40)$ using Motic Image Plus 2.0 program from 
Motic Instruments, Inc. (Richmond, British Columbia, Canada).

Propagation. Asexual reproduction was attempted using softwood cuttings and plant tissue culture. Softwood cuttings were taken in the spring or summer, dipped in $1000 \mathrm{ppm}$ $\mathrm{K}-\mathrm{IBA}$, and placed under intermittent mist in perlite or other similar medium. To introduce the hybrids into tissue culture, shoot tips 2 to $3 \mathrm{~cm}$ in length were collected and mature leaves were removed. The shoots were rinsed under running water for $1 \mathrm{~h}$ and were then surface-sterilized in a $0.53 \%$ solution of sodium hypochlorite and subsequently rinsed three times in sterile water under a laminar flow hood. A 3- to 5-mm shoot tip was then excised and placed into a test tube containing $15 \mathrm{~mL}$ of Linsmaier and Skoog media (Linsmaier and Skoog, 1965), $\mathrm{pH}$ adjusted to 5.7, without added plant growth hormones. To multiply in vitro plants, individual shoots were sectioned into two- to four-node pieces and placed on new media under the laminar flow hood. Axillary buds then formed new shoots for additional subcultures. Subcultures were accomplished monthly. Developing

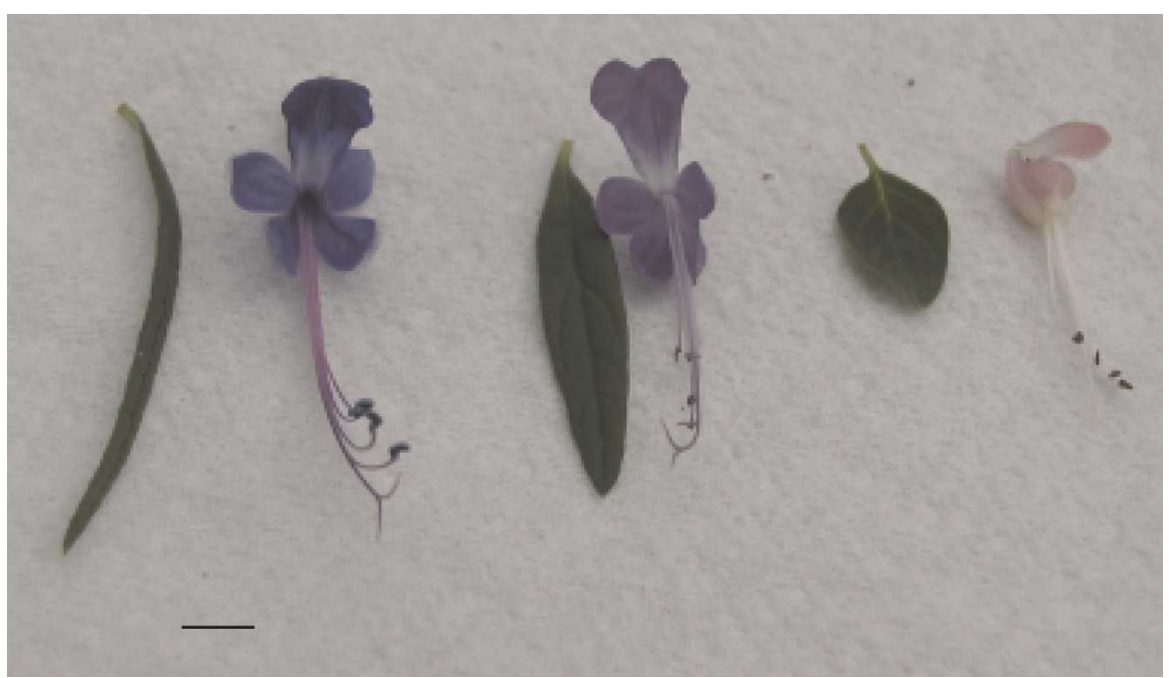

Fig. 1. Leaf and flower comparisons between $T$. lanatum (left), T. purpusii $\times$ T. lanatum (center), and T. purpusii (right). Bar $=7 \mathrm{~mm}$. shoots were then rooted and established as described for Itea virginica L. (Lindstrom and Pelto, 2003).

\section{Results and Discussion}

Five viable seedlings were obtained from the $T$. arizonicum (female) $\times T$. lanatum (male) cross, of which two later died. One viable seedling was obtained from the $T$. purpusii (female) $\times T$. lanatum (male) cross. For both crosses, no seeds resulted when $T$. lanatum was used as the female. This could be from the lack of pollen germination or insufficient pollen tube growth through the highly exserted style found on $T$. lanatum compared with the relatively shorter styles on T. arizonicum and T. purpusii.

Keeley and Fotheringham (1998) reported that $T$. lanatum seed would not germinate without coupling a year-long soil contact and smoke treatment, resulting in $\approx 30 \%$ germination. The smoke, having the active compound butenolide 3-methyl-2H-furo[2,3-c] pyran-2-one, is thought to allow a germination block to be overcome (Flematti et al.,
2004). No smoke or year-long soil contact treatment was administered to either group of hybrid seed $(\approx 15$ seeds total), and six seedlings resulted, indicating that extended soil and smoke treatments may be species specific. A smoke treatment may have increased the germination percentage. After initial seedlings had developed, a smoke treatment was applied to ungerminated seeds, with no success.

The $T$. purpusii $\times T$. lanatum hybrid, which flowered for the first time on 14 May 2007, unfortunately did not retain the unique pink corolla lobe color of T. purpusii. Corolla lobes were actually violet, which is intermediate in color between the two parents. This plant did show hybrid vigor in the anterior corolla lobe, as its size was greater than either parent (Fig. 1). Leaf, stamen, and pistil size were intermediate between the parents (Fig. 1; Table 1). Leaf and pistil morphology were also intermediate for the $T$. arizonicum $\times T$. lanatum hybrids, which flowered for the first time 15 May 2005; however, stamen length was shorter than either parent (Fig. 2; Table 1). Corolla lobe color for $T$. arizonicum $\times T$. lanatum hybrids were purple, and thus resemble the purple-blue flowers of T. lanatum.

The $T$. purpusii $\times T$. lanatum hybrid did set limited seed, whereas no seed has been produced by $T$. arizonicum $\times T$. lanatum hybrids for two consecutive years despite attempts to self and sib-cross the hybrids. The $T$. arizonicum $\times T$. lanatum hybrids were observed to have limited pollen production. Anthers were nondehiscent and uncharacteristically white, turning to brown upon maturity. Similar intermediate male sterile flowers, having white indehiscent anthers that turn brown, unlike fertile purple anthers, were noted in Rosmarinus officinalis L. (Ubera-Jiménez and Hidalgo-Fernández, 1992).

Microscopic examination revealed that pollen from $T$. arizonicum $\times T$. lanatum hybrids were roughly half the size of pollen from either parent. Additionally, the pollen of $T$. arizonicum $\times T$. lanatum hybrids were flaccid, ranging from elliptical to crescentshaped, indicating lack of maturity (Fig. 3,

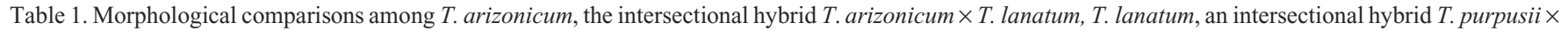
T. lanatum, and T. purpusii. Numeric data from at least five different samples.

\begin{tabular}{|c|c|c|c|c|c|}
\hline \multirow{2}{*}{ Characteristics } & \multirow[b]{2}{*}{ T. arizonicum } & \multirow{2}{*}{$\begin{array}{l}\text { T. arizonicum } \times \\
\text { T. lanatum }\end{array}$} & \multicolumn{3}{|c|}{ T. purpusii $\times$} \\
\hline & & & T. lanatum & T. lanatum & T. purpusii \\
\hline Growth habit & Subshrub & Shrub & Shrub & Shrub & Shrub \\
\hline Leaves $^{z}$ & $1.7-2.3$ & $4.6-5.5$ & $11.7-24.1$ & $3.7-5.6$ & $1.6-2.3$ \\
\hline Leaf shape & Ovate & Lanceolate & Linear/lanceolate & Linear & Ovate \\
\hline Leaf margin & Undulate & Entire & Entire & Entire & Entire \\
\hline Posterior corolla lobe $\mathrm{z}^{\mathrm{z}}$ & $1.6-3.2$ & $1.4-2.3$ & $1.3-2.6$ & $1.2-2.0$ & $1.5-2.0$ \\
\hline Anterior corolla lobe $(\text { lip })^{z}$ & $1.0-1.8$ & $1.1-1.6$ & $1.7-2.4$ & $0.9-1.8$ & $1.6-1.9$ \\
\hline Petal color ${ }^{\mathrm{y}}$ & 155B (white) & 86B (purple) & 93B (purple-blue) & 83B (violet) & $70 \mathrm{~B}$ (pink) \\
\hline Lip color ${ }^{\mathrm{y}}$ & $88 \mathrm{~A} / 155 \mathrm{~B}$ (violet/white) & 89B (royal purple) & 89B (royal purple) & $83 \mathrm{~B}$ (violet) & $70 \mathrm{~B}$ (pink) \\
\hline Pubescence & Sparse & Sparse & Dense & Sparse & Sparse \\
\hline Stamen length (mm) & $16-20$ & $9-15$ & $25-29$ & $14-20$ & $10-18$ \\
\hline Anther color ${ }^{\mathrm{y}}$ & 155A (off-white) & 1C (green-yellow) & 101B (blue) & 195A (gray-green) & 161A gray-yellow \\
\hline Filament color ${ }^{\mathrm{y}}$ & 155D (off-white) & $76 \mathrm{~A}$ light purple & 77B (wine) & 76A (pink-violet) & $155 \mathrm{C}$ (white) \\
\hline Pistil length (mm) & 23 & 27 & 33 & 29 & 20 \\
\hline Style color $^{\mathrm{y}}$ & 76D (light lavender) & 76A (light purple) & 83D (purple) & 76A (light purple) & 75D (white-purple) \\
\hline
\end{tabular}

${ }^{\mathrm{z}}$ Value given as a ratio of length/width.

${ }^{y}$ Color ratings based on the Royal Horticultural Society Color Chart (Royal Horticultural Society, 1966). 


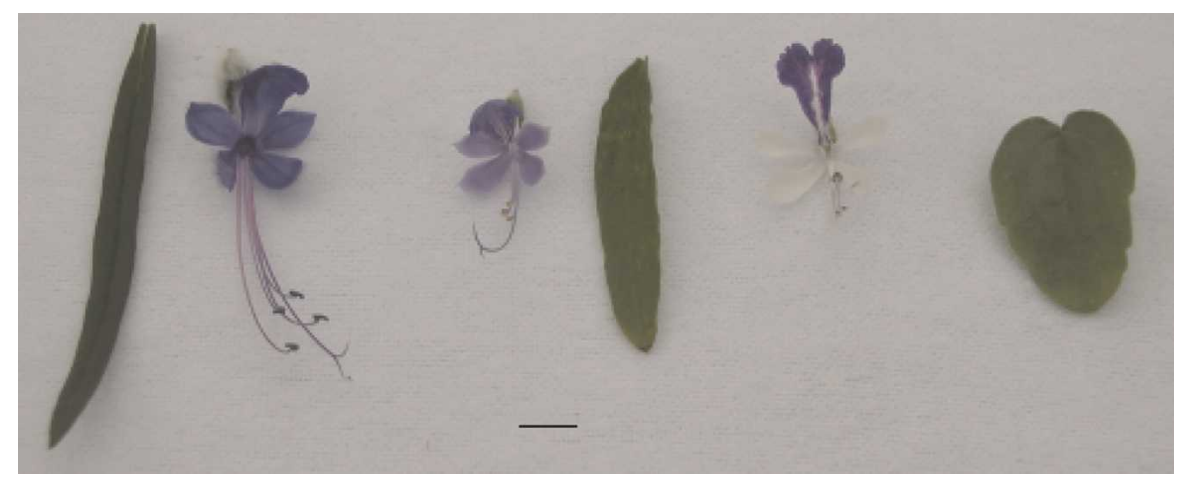

Fig. 2. Leaf and flower comparisons between T. lanatum (left), T. arizonicum $\times T$. lanatum (center), and T. arizonicum (right). Bar $=10 \mathrm{~mm}$.
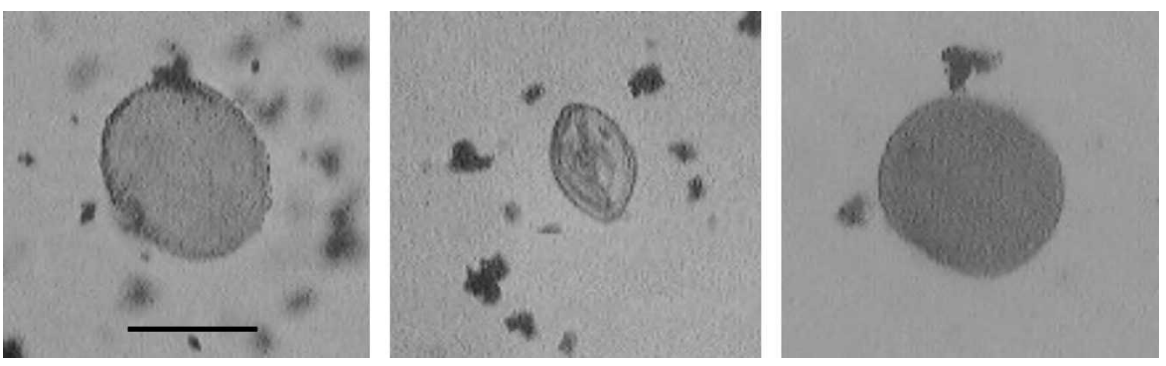

Fig. 3. Pollen comparisons of T. lanatum (left), T. arizonicum $\times T$. lanatum hybrid (center), and T. arizonicum (right). Bar $=50 \mu \mathrm{m}$.

Table 2. Average pollen size (in micrometers) and shape of 10 pollen grains for Trichostema lanatum, T. arizonicum, and T. arizonicum $\times$ T. lanatum hybrids.

\begin{tabular}{|c|c|c|c|c|c|c|c|}
\hline \multirow[b]{2}{*}{ Species } & \multicolumn{2}{|c|}{ Polar axis } & \multicolumn{2}{|c|}{ Equatorial axis } & \multicolumn{2}{|c|}{$\mathrm{P} / \mathrm{E}$ ratio } & \multirow[b]{2}{*}{ Pollen shape ${ }^{y}$} \\
\hline & $\overline{\text { Mean }}$ & $\overline{\text { Range }}$ & Mean & $\overline{\text { Range }}$ & $\overline{\text { Mean }}$ & $\overline{\text { Range }}$ & \\
\hline Trichostema & & & & & & & \\
\hline $\begin{array}{l}\text { Sect. Chromocephalum } \\
\text { T. lanatum } \\
\text { Sect. Paniculatum }\end{array}$ & 72.1 & $69-75$ & 60.1 & $55-65$ & 1.2 & $1.1-1.4$ & Euprolate \\
\hline $\begin{array}{l}\text { T. arizonicum } \\
\text { T. arizonicum } \times\end{array}$ & 67.6 & $60-76$ & 73.8 & $71-78$ & 0.9 & $0.8-1.1$ & $\begin{array}{l}\text { Prolate spheroidal- } \\
\text { subprolate }\end{array}$ \\
\hline T. lanatum hybrid & 44.7 & $40-50$ & 37.1 & $30-44$ & 1.2 & $0.9-1.7$ & Prolate \\
\hline
\end{tabular}

${ }^{\mathrm{z}}$ Sections with $n=10$ chromosomes.

${ }^{y}$ Shapes classified according to Walker and Doyle (1975).

Table 2). Sarkissian and Harder (2001) indicated that amount and quality of pollen, including size and morphology, are often important components of fitness and relate to mating success. Attempts to germinate pollen in vitro on Brewbaker and Kwack (1963) media were not successful.

The lack of fertility in the F1 plants from $T$. arizonicum $\times T$. lanatum crosses was not expected, as both plants are reported to have the same chromosome number (Lewis, 1960). It is known that hybrids resulting from taxonomically unrelated parents (such as those from different sections) tend to be sterile or of low fertility (Qureshi et al., 2002). Sterile hybrids were also seen in the genus Calylophus Spach., where the high degree of sterility in certain intrasectional crosses was found to be correlated with cytological differences between the parental plants (Towner, 1977).

In an effort to have fertile plants for future breeding, a solution of $7 \mu \mathrm{m}$ oryzalin was applied as a mist using a spray bottle on a few emerging seedlings, which were derived from repeating earlier crossing experiments between $T$. arizonicum and T. lanatum. Inducing polyploidy is a viable method for improving meiotic pairing and restoring fertility in wide crosses (Sanford, 1983). A single plant (likely mixoploid) resulted from this study. The main stem on this plant branched, so that half of the plant produced branches with flowers that had enhanced flower size, corolla lobe color, stamen length, pollen production, and fertility (Fig. 4). Crosses between this oryzalin-induced hybrid and T. lanatum produced nutlets, indicating that the sterility seen in the original $T$. arizonicum $\times T$. lanatum crosses was likely from a meiotic imbalance.

Propagation of the hybrids was not difficult, as softwood cuttings rooted at high percentages within 2 to 3 weeks (data not shown). We were also successful in propagating both hybrids by plant tissue culture.

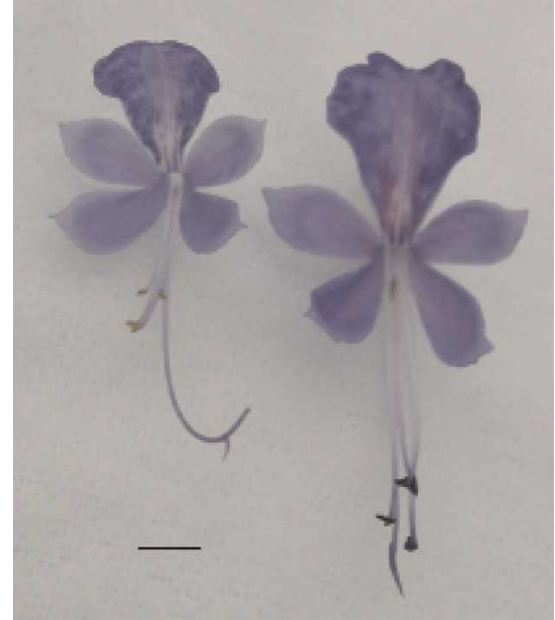

Fig. 4. Flower comparison between untreated (left) and oryzalin-treated $\mathrm{T}$. arizonicum $\times \mathrm{T}$. lanatum seedling (right). Bar $=5 \mathrm{~mm}$.

By establishing plants in tissue culture, large numbers of plants can be generated quickly without having to maintain a large number of stock plants.

The taxonomic significance of the intersectional hybrids $T$. arizonicum $\times T$. lanatum and $T$. purpusii $\times T$. lanatum provides genetic evidence that the genomes are sufficiently homologous to permit the formation of hybrids. In the case of $T$. purpusii $\times T$. lanatum, these hybrids are fertile. The sterility and later restored fertility seen in the $T$. arizonicum $\times$ T. lanatum hybrids indicate that these two taxa are less related. We can also conclude that although $T$. arizonicum and $T$. purpusii are found in different sections than $T$. lanatum, these species may be more closely related than is apparent from their present classification in distinct sections. This goes against Huang (2002), who found that sect. Chromocephalum is a sister group to the remainder of the genus after she combined morphological and molecular data. These intersectional hybrids may be viewed as evidence for the feasibility of crossing other Trichostema species, having similar chromosome numbers, within and among sections. The fact that oryzalin was successful in restoring fertility further expands the breeding potential among wide crosses within Trichostema. An important result of continued hybridization studies may well be a greatly improved understanding of the taxonomy of this genus. The data we collected agrees with Spira (1978) who reported that flower size and reproductive parts vary greatly within Trichostema species. The $T$. purpusii $\times T$. lanatum hybrid has not been selected for release as of yet; however, one $T$. arizonicum $\times T$. lanatum hybrid was selected and released as 'Blue Myth' (Dunn and Lindstrom, 2007).

\section{Literature Cited}

Brewbaker, J.L. and B.Y. Kwack. 1963. The essential role of calcium ion in pollen germination 
and pollen tube growth. Amer. J. Bot. 50:859865.

Clausen, R.R. and N.H. Ekstrom. 1989. Perennials for American gardens. Random House, New York.

Crane, K. 2007. Yerba Buena Nursery (Trichostema lanatum). 13 May 2007. http://www. yerbabuenanursery.com/online_album/0810. htm.

Dalby, R. 2004. Blue Curls. Amer. Bee J. 144:127-128.

Dunn, B.L. and J.T. Lindstrom. 2007. 'Blue Myth' Trichostema. J. Environ. Hort. 25:250-251.

Epling, C. 1940. Supplementary notes of American Labiatae. Bull. Torrey Bot. Club 67:509-534.

Evans, M. and J. Bohn. 2001. Trichostema lanatum, Woolly Bluecurls. 13 May 2007. <http:// www.treeoflifenursery.com/main/PDFs/PlantProfiles/Trich_lana.pdf $>$.

Flematti, G.R., E.L. Ghisalberti, K.W. Dixon, and R.D. Trengove. 2004. A compound from smoke that promotes seed germination. Science 305:977.

Heisey, R.M. and C.C. Delwiche. 1984. Phytotoxic volatiles from Trichostema lanceolatum (Labiatae). Amer. J. Bot. 71:821-828.

Henrickson, J. 1982. On the recognition of Trichostema mexicanum Epling (Lamiaceae). Madrono 29:104-108.

Huck, R.B. 1992. Overview of pollination biology in the Lamiaceae, p. 167-181. In: R.M. Harley and T. Reynolds (eds.). Advances in Labiate science. Royal Botanic Gardens, Kew, UK.

Keeley, J.E. and C.J. Fotheringham. 1998. Smokeinduced seed germination in California Chaparral. Ecology 79:2320-2336.

Kruckeberg, A.R. 1962. Intergeneric hybrids in the Lychnideae (Caryophyllaceae). Brittonia 14:311-321.

Lewis, H. 1945. A revision of the Genus Trichostema. Brittonia 5:276-303.

Lewis, H. 1960. Chromosome numbers and phylogeny of Trichostema. Brittonia 12:93-97.

Lewis, H. 2006. Trichostema ruygtii (Lamiaceae): A new species from Napa county, California. Madrono 53:282-287.

Lewis, H. and J. Rzedowski. 1978. The genus Trichostema (Labiatae) in Mexico. Madrono 25:151-154.

Lindstrom, J.T. and M.C. Pelto. 2003. Micropropagation of Virginia sweetspire (Itea virginica 'Henry's Garnet'). J. Environ. Hort. 21:206208.

Linsmaier, E.M. and F. Skoog. 1965. Organic growth factor requirements of tobacco tissue cultures. Physiol. Plant. 18:100-128.

Huang, H. 2002. Systematics of Trichostema L. (Lamiaceae) and phylogenetic relationships with its disjunct taxa in Asia. Ohio State University, Columbus, $\mathrm{OH}, \mathrm{PhD}$ dissertation.
Qureshi, S.J., A.G. Awan, M.A. Khan, and S. Bano. 2002. Study of pollen fertility of the genus Launaea from Pakistan. Asian J. Plant Sci. 1:73-74.

Sarkissian, T.S. and L.D. Harder. 2001. Direct and indirect responses to selection on pollen size in Brassica rapa L. J. Evol. Biol. 14:456-468.

Sanford, J.C. 1983. Ploidy manipulations, p. 100123. In: J.N. Moore and J. Janick (eds.). Methods in fruit breeding. Purdue University Press, West Lafayette, IN.

Spira, T.P. 1978. Floral parameters associated with breeding system and pollinator type in Trichostema (Labiatae). California State University, Chico, CA, MA thesis.

Towner, H.F. 1977. The biosystematics of Calylophus (Onagraceae). Ann. Mo. Bot. Gard. 64:48-120.

Ubera-Jiménez, J.L. and P.J. Hidalgo-Fernández. 1992. Temporal gynodiocy in Rosmarinus officinalis, p. 281-289. In: R.M. Harley and T. Reynolds (eds.). Advances in Labiate science. Royal Botanic Gardens, Kew, UK.

Walker, J.W. and J.A. Doyle. 1975. The basis of angiosperm phylogeny. Ann. Mo. Bot. Gard. 62:664-723.

Wilson, B. 2007. Trichostema lanatum Woolly Blue Curls. 1 May 2007. <http://www.laspilitas.com/ plants/680.htm>. 